\title{
The antibacterial and antibiofilm activity of sea anemone (Stichodactyla haddoni) against antibiotic-resistant bacteria and characterization of bioactive metabolites
}

\author{
Homa Hamayeli • Mehdi Hassanshahian $(\mathbb{D} \cdot$ Majid Askari \\ Hesni
}

Received: 27 November 2018/Accepted: 8 March 2019/Published online: 15 March 2019

(C) The Author(s) 2019

\begin{abstract}
Sea anemones produce many biologically active compounds including neurotoxins, pore-forming toxins, phospholipases and proteinase inhibitors. The Persian Gulf is an unexplored environment and maybe a rich source of marine natural products. The aim of this study is screening and identification of bioactive metabolites from Stichodactyla haddoni (Haddon's sea anemone) collected at the Persian Gulf. The crude extract of the sea anemone (tentacle, disc and total body) was obtained by methanol solvent. The antibacterial assays were carried out by the disc diffusion method. The antibiofilm activity (biofilm formation, biofilm destruction and reduction of metabolic activity) of the sea anemone extracts was evaluated by microtiter plate method. The bioactive compounds were identified by GC-MS analysis. Data showed that the best antibacterial effect (relate to P. aeruginosa) is obtained from extracts of "total body" section. Values of minimum inhibitory concentration and minimum bactericidal concentration show that the maximum antibacterial activity takes place at $10-20 \mathrm{mg} / \mathrm{ml}$ concentration. Three parts of sea anemone exhibit different inhibition against biofilm of bacteria, in particular, inhibition of biofilm observed by the tentacle, disc and total body against $P$. aeruginosa, $K$. pneumonia and $A$. baumannii, respectively. Biofilm of $P$. aeruginosa was the most sensitive and the biofilm of $B$. cereus was the most resistant structure between all pathogenic bacteria. The best reduction in the metabolic activity was observed in $P$. aeruginosa and $K$. pneumonia among tested bacteria. Aliphatic compounds were predominant bioactive metabolites in this sea anemone. The marine animal and especially sea anemone produce useful bioactive compounds that can be used to prevent bacterial biofilm; application of bioactive materials, reported in this study, can be proposed for future studies.
\end{abstract}

Keywords Antimicrobial activity $\cdot$ Biofilm $\cdot$ Stichodactyla haddoni $\cdot$ Bioactive metabolites $\cdot$ Aliphatic compounds

\section{Introduction}

The marine environment is an exceptional reservoir of natural products, many of which exhibit structural features, not found in terrestrial natural products. Marine invertebrates, especially sedentary sea anemones are evolved with rich sources of bioactive metabolites, which could be used for novel antimicrobial drugs (Prakash et al. 2007; Mohammadi et al. 2019).

Cnidaria is simple animals with radial symmetry that contain two layers of cells, ectoderm, and endoderm. Mesoglea, a non-cellular matrix, is present between the two layers. Cnidaria feeding success relies on the

H. Hamayeli · M. Hassanshahian $(\bowtie) \cdot$ M. Askari Hesni

Department of Biology, Faculty of Sciences, Shahid Bahonar University of Kerman, Kerman, Iran e-mail: mshahi@uk.ac.ir 
presence of the specialized poisonous cell, the nematocysts. These organisms have specialized subcellular organelles called cnidae with several structures and functions. Cnidae can be classified into three types: nematocysts, spirocysts, and ptychocysts. Nematocysts deliver the venom through the skin, whereas spirocysts are adhesive and ptychocysts are involved in protection (Frazão et al. 2012; Masoumipour et al. 2018).

The Cnidaria is a large, diverse, and ecologically important phylum. It includes about 9400 species, of which $68 \%$ are members of the class Anthozoa. Many anthozoans reproduce through both asexual and sexual means (Schlesinger et al. 2010). In common with all animals, anthozoans need to protect themselves against the lethal or debilitating consequences of microbial or parasitic invasion (Hutton and Smith 1996).

The microbiome of certain marine invertebrates may represent a remarkable proportion of the holobiont biomass, with anthozoan cnidarians being no exception and hosting abundant and diverse communities of bacteria. Certain species able to secrete mucus may reach microbial concentrations up to 1000 -fold higher than those observed in seawater. While microbial communities associated with tropical reef-building corals are already starting to be unraveled, those colonizing other groups of anthozoans are still largely unknown (Rocha et al. 2014).

Sea anemones, like other coelenterates, produce many biologically active polypeptides and proteins, including neurotoxins, pore-forming toxins (or cytolysins), phospholipases and proteinase inhibitors (Thangaraj and Bragadeeswaran 2012; Sepehri et al. 2016). Therefore, they have evolved the ability to synthesize toxic compounds obtained from marine microorganisms. These compounds help them deter predators, keep a competitor at bay or paralyze their prey (Ghosh et al. 2011). Substances exhibit a wide diversity of biological activities such as hemolysis, cytotoxicity, cardiotropic activity, membrane depolarization and the block of potassium channels (Gunasundari et al. 2013; Hamayeli et al. 2016).

Sea anemone shows a very good symbiotic partnership with the marine ornamental fishes, especially with clowns. Some of these fish species possess considerable resistance to the sea anemone but appear to be mainly protected by a mucous coat which prevents discharge of the nematocyst (Mohsenipour and Hassanshahian 2015).

As a consequence of increasing demand for the biodiversity in the screening programs seeking therapeutic drugs from natural products, there is now a greater interest in marine organism. There is a copious number of works pertaining to the antibacterial agents from marine bacteria, microalgae, seaweeds, sponges, mollusks and ascidians (John et al. 2015; Mashhadi et al. 2016).

These organisms can attach to living and non-living surfaces like medical devices which include urinary, venous, and arterial catheters, shunts, heart valves and tubes (Prasanna and Doble 2008). According to a publication by the National Institutes of Health, more than $80 \%$ of all infections involve biofilms (Afreenish et al. 2011; Masoumipour et al. 2018).

Microbial adhesion to surfaces and the consequent biofilm formation have been documented in many different environments. Biofilms constitute a protected mode of growth that allows microorganisms to survival in hostile environments, being their physiology and behavior significantly different from their planktonic counterparts. They are difficult to eradicate due to their resistant phenotype (Simões et al. 2010).

There are several advantages for microorganisms to form biofilms. They provide enclosed surface space which is occupied and can provide a degree of stability in the growth environment. They might have catalytic functions through the localizing cells in close proximity. Microbial biofilms have been associated with a lot of persistent infections which respond poorly to antibiotic therapy and can withstand host immune response (Atray and Atray 2015). Microbial resistance is a natural biological response of microbes to selective pressure, such as weather conditions, food, oxygen or water availability, or the presence of an antimicrobial drug (Soares et al. 2012). The familiar mechanisms of antibiotic resistance, such as efflux pumps, modifying enzymes, and target mutations, do not seem to be responsible for the protection of bacteria in a biofilm (Stewart and Costerton 2001).

Correcting a resistance problem, then, requires both improved management of antibiotic use and restoration of the environmental bacteria susceptible to these drugs (Odonkor and Addo 2011).

Sea anemones are evolved with rich sources of bioactive metabolites, which could be used for novel antimicrobial drugs, many of which exhibit structural features, not found in terrestrial natural products. Some natural products were extracted from marine organisms, but less than $1 \%$ has been examined so far for pharmacological activity (Subramanian et al. 2011). The Persian Gulf is an unexplored environment and maybe a rich source of marine natural products. In this optic, there are few reports on the bioactivity of the 
Iranian Stichodactyla haddoni (Haddon's sea anemone). The aim of this investigation is screening and identification of bioactive metabolites from S. haddoni that collected at the Persian Gulf. Also, the antibacterial and antibiofilm activity of this sea anemone extracts against some pathogenic bacteria were evaluated.

\section{Materials and methods}

Sea anemone collection and identification

The sea anemone organisms were collected, in November 2015, at Gheshm Islands (N 26.994086, E 56.194300, Persian Gulf, Iran). All organisms were gathered from a depth of 1-5 m. Organisms have transported alive in seawater to a laboratory and maintained at $4{ }^{\circ} \mathrm{C}$ in a refrigerator before extraction. The characterization of an exemplar of the sea anemone was identified according to the protocol of Raghunathan et al. (2014). Identification revealed that organisms collected are Stichodactyla haddoni (Haddon's sea anemone), a species of sea anemone belonging to the Stichodactylidae family native from the Indo-Pacific area. The macroscopic image of this sea anemone is shown in Fig. (1).

Extraction of bioactive metabolites from sea anemone

Collected of S. haddoni were separated into two sections: tentacle and disc. Also, total body (mixture of whole body of this marine animal) was extracted. For extraction of biomolecules, separate sections (of sea anemones) were freeze-dried. Each part of sea anemone was immersed into a polar solution with methanol $(\mathrm{MeOH})$ for $48 \mathrm{~h}$. Then, the obtained extracts were filtrated and concentrated. Each extract passed through Whatman No. 1 filter paper. The filtrates were placed into an incubator at $40 \pm 1{ }^{\circ} \mathrm{C}$ for $24 \mathrm{~h}$ to remove residual of a solvent. The concentrated extracts were applied for antimicrobial activity against pathogenic bacteria (Eash-Loucks and Fautin 2012).

\section{Bacteria}

Six antibiotic-resistant pathogenic bacteria were used in this study: Pseudomonas aeruginosa ATCC 27853, Acinetobacter baumannii ATCC 1611, Bacillus cereus ATCC 1298, Klebsiella pneumoniae ATCC 700603, Escherichia coli ATCC 35218, Staphylococcus aureus ATCC 1189. All bacterial strains, used in this study, were obtained from American Type Culture Collection, USA.

Disk diffusion method

Antibacterial activity of the extract (of three sections of sea anemone) was tested by the standard disc diffusion method. The turbidity of bacteria culture reached 0.5 Mac-Farland standards $\left(10^{8} \mathrm{CFU} \mathrm{mL}^{-1}\right)$; then, one

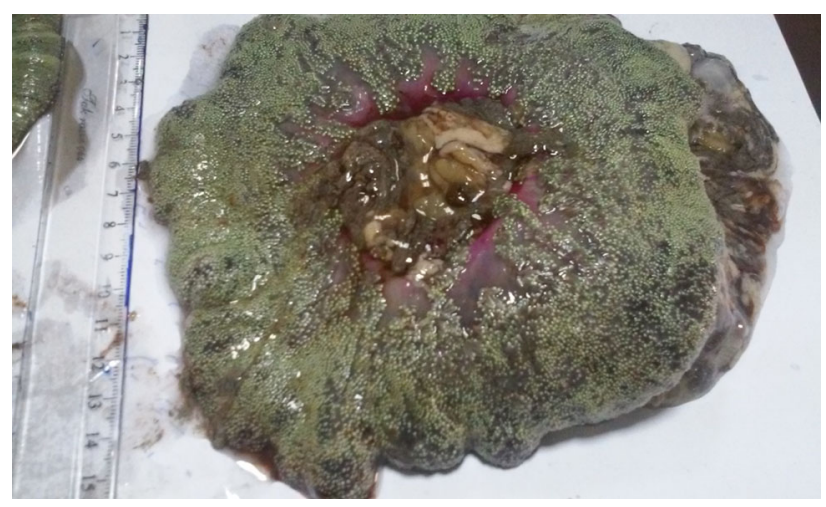

Fig. 1 Macroscopic pictures of sea anemone S. haddoni studied in this research 
milliliter of this inoculum was transferred into Mueller-Hinton Agar (MHA) plates by a spread plate method using a sterile cotton swab and allowed to stay for $60 \mathrm{~s}$. A concentration of each extract $\left(0.15 \mathrm{mg} \mathrm{mL}^{-1}\right)$ was placed in a sterile filter paper discs $(\varnothing, 6 \mathrm{~mm})$; samples were placed in plates for $1 \mathrm{~h}$. After incubation, the discs were put $(30 \mathrm{~min})$ at room temperature and transferred to the medium. Disc solvent-free extract was used as a negative control. The zone of inhibition (ZOI) of each disc (contained sea anemone's extracts) was calculated in millimeter and the measurements were performed in triplicate (Mohsenipour and Hassanshahian 2016, 2002; Boyanova et al. 2005).

Determination of MIC and MBC of sea anemone extract

Minimal Inhibitory Concentration (MIC) was determined by serial dilution method using 96-well microtiter plates. The different sea anemone's extracts were taken $(1 \mathrm{mg} / \mathrm{mL})$ and serial dilutions of the extracts were prepared with Mueller-Hinton broth medium. The microplates were incubated for $24 \mathrm{~h}$ at $37^{\circ} \mathrm{C}$. The lowest concentrations without visible growth at the binocular microscope were recorded as MIC. The Minimal Bactericidal Concentration (MBC) was characterized by spreading $50 \mu \mathrm{L}$ on MHA plate from the sample showing no visible growth; plates were incubated for $18 \mathrm{~h}$ at $37{ }^{\circ} \mathrm{C}$ (Silveira et al. 2009; Jabra-Rizk et al. 2006; Rosenberg and Rosenberg 1981).

Inhibition of biofilm formation

Biofilm formation in polystyrene microtiter plates was assayed as described by O'Toole and Kolter with some modifications (O'Toole and Kolter 1998). Three different extract concentrations $(25,12.5$ and $6.25 \mathrm{mg} / \mathrm{ml})$ were pipetted $(100 \mu \mathrm{l})$ into the wells of the microtiter plates. Then, an overnight culture of each bacterial species was diluted 1:100 with fresh TSB and $100 \mu \mathrm{l}$ of these inoculums was added to each well. Thereafter, microtiter plates were incubated for $24 \mathrm{~h}$ at $37^{\circ} \mathrm{C}$. Three control wells were maintained for each test. These include wells containing extract and growth medium (extract control); the wells containing the growth medium and inoculum and the wells containing only the growth medium (Saeidi et al. 2015).

The attached biofilm mass was quantified using crystal violet staining. After incubation, the media were aspirated and non-adherent cells were removed by washing the wells three times with sterile phosphate buffer saline (PBS). To fix the adherent cells, $150 \mu \mathrm{l}$ of methanol $96 \%$ was added to each well for $15 \mathrm{~min}$. The microtiter plates were then stained with $200 \mu \mathrm{l}$ of crystal violet $1 \%$ (Merck, Germany) for $20 \mathrm{~min}$, excess stain rinsed off with running tap water. The plates were air dried and the CV bound to adherent cells was solubilized with $160 \mu \mathrm{l} 33 \%$ glacial acetic acid per well. The absorbance of each well was monitored with a microtiter plate reader (ELX-800, Biotec, India) at $630 \mathrm{~nm}$. Percent inhibition of biofilm formation was calculated using the ratio between the values of $\mathrm{OD}_{630 \mathrm{~nm}}$ wells with and without the extracts.

$$
\begin{aligned}
\% \text { inhibition }= & (\text { OD negative control }- \text { OD media control }) \\
& -(\text { OD test }- \text { OD extract control }) /(\text { OD negative control }- \text { OD media control }) \times 100
\end{aligned}
$$

Disruption of an on established biofilm

Disruption of established biofilm structures was measured as described by Sandasi with some modifications (Sandasi et al. 2008). Biofilms were established in the microtiter plates by growing $100 \mu \mathrm{l}$ of the standard bacterial culture $\left(\mathrm{OD}_{600 \mathrm{~nm}}=0.2\right)$ for $24 \mathrm{~h}$ at $37^{\circ} \mathrm{C}$. After incubation, the medium was aspirated and the planktonic cells were removed by washing the biofilms three times with sterile PBS 1x. Thereafter, three different concentrations $\left(25,12.5\right.$ and $\left.6.25 \mathrm{mg} \mathrm{mL}^{-1}\right)$ of extracts were added to each well and plates were incubated at $37{ }^{\circ} \mathrm{C}$ for $24 \mathrm{~h}$. The control wells were the same as those described above. The percentages of biofilm eradication in the presence of different concentrations of extracts were calculated according to the formula as described earlier. 
The efficiency of sea anemone extracts on metabolic activity of biofilm

Pre-formed biofilms were washed twice with PBS 1x. Three different concentrations $(25,12.5$ and $6.25 \mathrm{mg} \mathrm{mL}{ }^{-1}$ ) of $S$. haddoni extracts were added to microplates; these were incubated for $24 \mathrm{~h}$ at $37^{\circ} \mathrm{C}$. After incubation, $50 \mu \mathrm{l}$ of a Triphenyl Tetrazolium Chloride (TTC; Merck, Germany) solution was added at the samples in the study. Microplates as prepared were incubated (in the dark) at $37{ }^{\circ} \mathrm{C}$ for $3 \mathrm{~h}$. TTC reduction was also measured with a microplate reader at $490 \mathrm{~nm}$. The percentages of biofilm metabolic activity reduction in the presence of different concentrations of extracts were calculated using the formula as described earlier (Lazarova et al. 1994; Sadeghian et al. 2012).

Gas chromatography-mass spectrometry (GC-MS) analysis of S. haddoni extracts

The $S$. haddoni extracts were analyzed by GC-MS for determination of bioactive metabolites. The GC-MS analysis was performed on Varian Saturn 2000 GC-MS (Agilent Technology). Specifications detectors are Mass range from 10 to $650 \mathrm{amu}$. An HP-5MS column of 60-m length, $0.25-\mathrm{mm}$ diameter, and $0.25-\mu \mathrm{m}$ film thickness was used. The oven was programmed from a primary temperature $70{ }^{\circ} \mathrm{C}$ (hold for $2 \mathrm{~min}$ ) to the terminal temperature $300{ }^{\circ} \mathrm{C}$ at the rate of $10(35.0 \mathrm{~min})$. The final temperature hold-up time was $10 \mathrm{~min}$. Helium at the rate of $1 \mathrm{ml} / \mathrm{min}$ was used as the carrier gas in constant flow mode. The inlet and interface temperatures were kept at $2800{ }^{\circ} \mathrm{C}$. The EI source was operated at $2300{ }^{\circ} \mathrm{C}$ and the quadruple temperature was $5000{ }^{\circ} \mathrm{C}$. The MS was scanned from 1 to $3000 \mathrm{~m} / z$. One microliter of the sample was injected in split mode at a split ratio of 40. WILEY library search was used for compound identifications (Rani Juneius and Selvin 2012).

Statistical analysis

Differences for individual parameters between control and treated groups were tested with Duncan's test by analysis of variance (ANOVA) using SPSS Version 16.0 for Windows. Differences were considered significant if the $\mathrm{P}$ value was less than $0.01,0.05$ and 0.001 . All experiments were performed in triplicate and repeated three times.

\section{Results}

Inhibitory effects of three extracts of sea anemone against planktonic forms of bacteria

The zone of inhibition (ZOI) for metabolic extracts of three parts (tentacle, disc and total body) of sea anemone's extracts is shown in Table 1, also the MIC and MBC values of these extracts are illustrated in Table 1. According to this table, the best antibacterial effect of sea anemone extracts relates to P. aeruginosa. Between three parts of sea anemone, the optimum inhibitory effect belongs to the total body. The MIC and MBC values show that the maximum antibacterial activity takes place at $10-20 \mathrm{mg} / \mathrm{ml}$ concentration (Table 1).

Antibiofilm properties of $S$. haddoni extracts

The antibiofilm activity of $S$. haddoni extracts against six pathogenic bacteria was assayed by two methods include biofilm inhibition and biofilm destruction. The results for biofilm inhibition are presented in Fig. (2ac). This figure revealed that three parts of sea anemone exhibited different inhibition against biofilm of bacteria. As, three parts of sea anemone (tentacle, disc and total body) had the most effective anti-biofilm activity against $P$. aeruginosa, $K$. pneumoniae and A. baumannii respectively.

The results for biofilm destruction are shown in Fig. (3a-c). For the destruction of the biofilm structures, the biofilm of $P$. aeruginosa was the most sensitive and the biofilm of B. cereus was the resistant structure between all tested pathogenic bacteria. 
Table 1 The antimicrobial effect of $S$. haddoni extracts against six planktonic bacteria

\begin{tabular}{|c|c|c|c|c|c|c|c|}
\hline & \multirow{2}{*}{$\begin{array}{l}\text { S. haddoni } \\
\text { extracts }\end{array}$} & \multicolumn{6}{|l|}{ Bacterial strains } \\
\hline & & $\begin{array}{l}\text { Pseudomonas } \\
\text { aeruginosa }\end{array}$ & $\begin{array}{l}\text { Acinetobacter } \\
\text { baumannii }\end{array}$ & $\begin{array}{l}\text { Bacillus } \\
\text { cereus }\end{array}$ & $\begin{array}{l}\text { Klebsiella } \\
\text { pneumoniae }\end{array}$ & $\begin{array}{l}\text { Escherichia } \\
\text { coli }\end{array}$ & $\begin{array}{l}\text { Staphylococcus } \\
\text { aureus }\end{array}$ \\
\hline \multirow{3}{*}{$\begin{array}{l}\text { Disk diffusion } \\
(\varnothing, \mathrm{mm})\end{array}$} & Tentacle & $12 \pm 0.3 \mathrm{SD}$ & $11 \pm 0.3 \mathrm{SD}$ & $8 \pm 0.6 \mathrm{SD}$ & $10 \pm 0.5 \mathrm{SD}$ & $8 \pm 0.2 \mathrm{SD}$ & $14 \pm 0.6 \mathrm{SD}$ \\
\hline & Disc & $11 \pm 0.5 \mathrm{SD}$ & $9 \pm 0.3 \mathrm{SD}$ & $10 \pm 0.2 \mathrm{SD}$ & $11 \pm 0.3 \mathrm{SD}$ & $10 \pm 0.5 \mathrm{SD}$ & 0 \\
\hline & Total & $14 \pm 0.2 \mathrm{SD}$ & $12 \pm 0.4 \mathrm{SD}$ & $11 \pm 0.5 \mathrm{SD}$ & $12 \pm 0.2 \mathrm{SD}$ & $10 \pm 0.3 \mathrm{SD}$ & $12 \pm 0.2 \mathrm{SD}$ \\
\hline \multirow[t]{3}{*}{$\mathrm{MIC}\left(\mathrm{mg} \mathrm{mL}^{-1}\right)$} & Tentacle & 20 & 20 & 40 & 10 & 40 & 10 \\
\hline & Disc & 20 & 10 & 20 & 20 & 20 & 40 \\
\hline & Total & 20 & 20 & 20 & 20 & 10 & 20 \\
\hline \multirow[t]{3}{*}{$\mathrm{MBC}\left(\mathrm{mg} \mathrm{mL}^{-1}\right)$} & Tentacle & 80 & 80 & 80 & 40 & 80 & 40 \\
\hline & Disc & 80 & 40 & 40 & 80 & 40 & 80 \\
\hline & Total & 40 & 40 & 80 & 80 & 40 & 80 \\
\hline
\end{tabular}

The efficiency of $S$. haddoni extract on biofilm metabolic activity

Metabolic activity of bacteria in biofilm structure that was treated with a total of the disc and tentacle of $S$. haddoni extract had considerably decreased. The results are depicted in Fig. (4). As shown in this figure, the best reduction in the metabolic activity was seen in $P$. aeruginosa and $K$. pneumonia among the tested bacteria. However, S. aureus and A. baumannii had a low reduction in metabolic activity compared to other bacteria (Fig. 4).

Statistical analysis

The effect of bacteria genus and different concentration of sea anemone extracts on biofilm formation and destruction was analyzed statistically by Duncan's test. The results are presented in Table 2. This table confirmed that for biofilm inhibition and destruction, S. haddonni extract was significant at $(p<0.05$ and $p<0.01$, respectively).

The chemical composition of $S$. haddoni extract

The bioactive compounds that exist in the crude extract of $S$. haddoni were determined by GC-MS. The results are presented in Table 3. Table 3 confirmed that the major compounds in the $S$. haddoni extract can be classified into three groups: aliphatics, alicyclic and aromatics. Aliphatic compounds were predominant between these materials (Table 3).

\section{Discussion}

A small number of marine microbes, plants and animals have already yielded more than 16,000 novel compounds with hundreds of new compounds still being discovered every year (Raghunathan et al. 2014; Ghosh et al. 2011). All sea anemone produce venom which is delivered by the specialized sting in organelles, known as nematocysts, located on body surfaces and in high concentration on tentacles (Bragadeeswaran et al. 2011; Khoddami et al. 2018).

The antimicrobial activity of the sea anemone was studied by some researchers in the world; Williams et al. (2007) evaluated antimicrobial activity and associated bacteria from benthic sea anemone S. haddoni against some pathogens. They concluded that the hexane tissue extract of the sea anemone showed optimum sensitivity $(24 \mathrm{~mm})$ against the fish bacterial pathogen Aeromonas hydrophila than the other chosen pathogens. Comparatively, the tissue extracts showed promising antimicrobial sensitivity than the cell-free extracts of associated bacteria, and hence, the tissue samples from the sea anemone $S$. haddoni are recommended for further exploration of novel antimicrobial drugs than the associated bacteria (Prakash et al. 2007). 

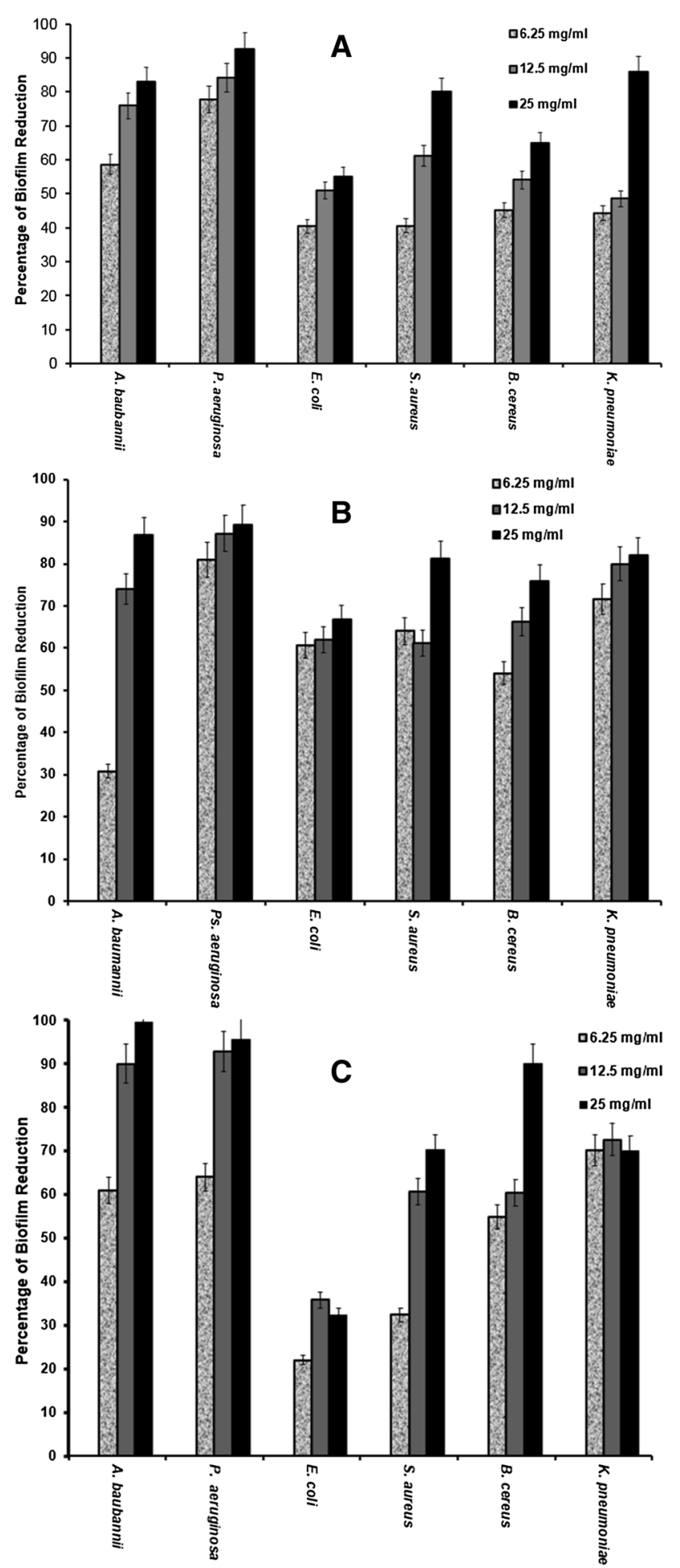

Fig. 2 Percentage reduction of biofilm formation for test bacteria treated with different concentrations of $S$. haddoni extracts from tentacle (a), disc (b) and total (c) for $24 \mathrm{~h}$

Thangaraj et al. (2011) collected two sea anemone species from the coast of India and studied the antimicrobial activity of them. Their results showed that the antibacterial and antifungal activities were predominant in the crude extract of the Stichodactyla mertensii and Stichodactyla gigantean. The butanol and acetone extract of $S$. mertensii showed roughly $8 \mathrm{~mm}$ zone of inhibition against $E$. coli and Proteus mirabilis in the methanolic extract (Thangaraj et al. 2011). 

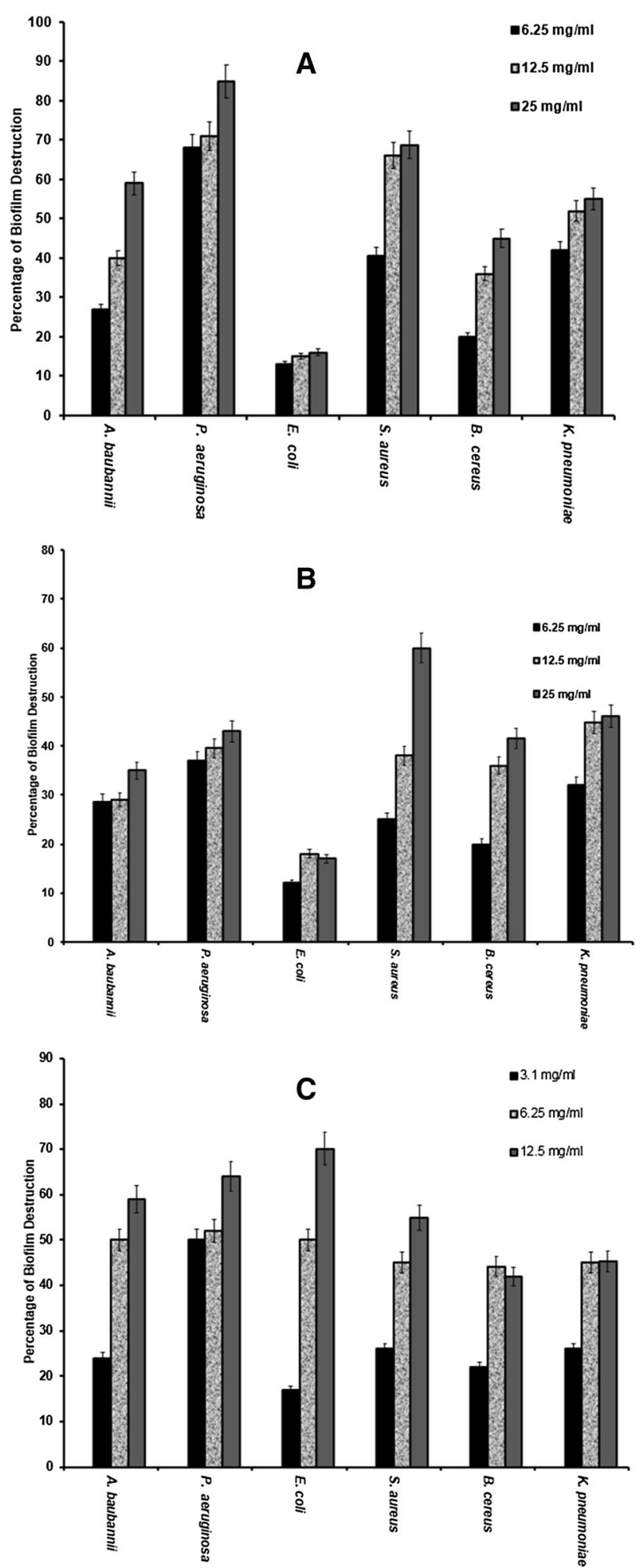

Fig. 3 Percentage disruption of biofilm for test bacteria treated with different concentrations of $S$. haddoni extracts tentacle (a), disc (b) and total (c) for $24 \mathrm{~h}$

Gunasundari et al. (2013) screened and isolated the antibiotic compounds from the mucus of sea anemone Heteractis magnifica. Also, they evaluated the antimicrobial activity of this antibiotic against fish pathogens. 


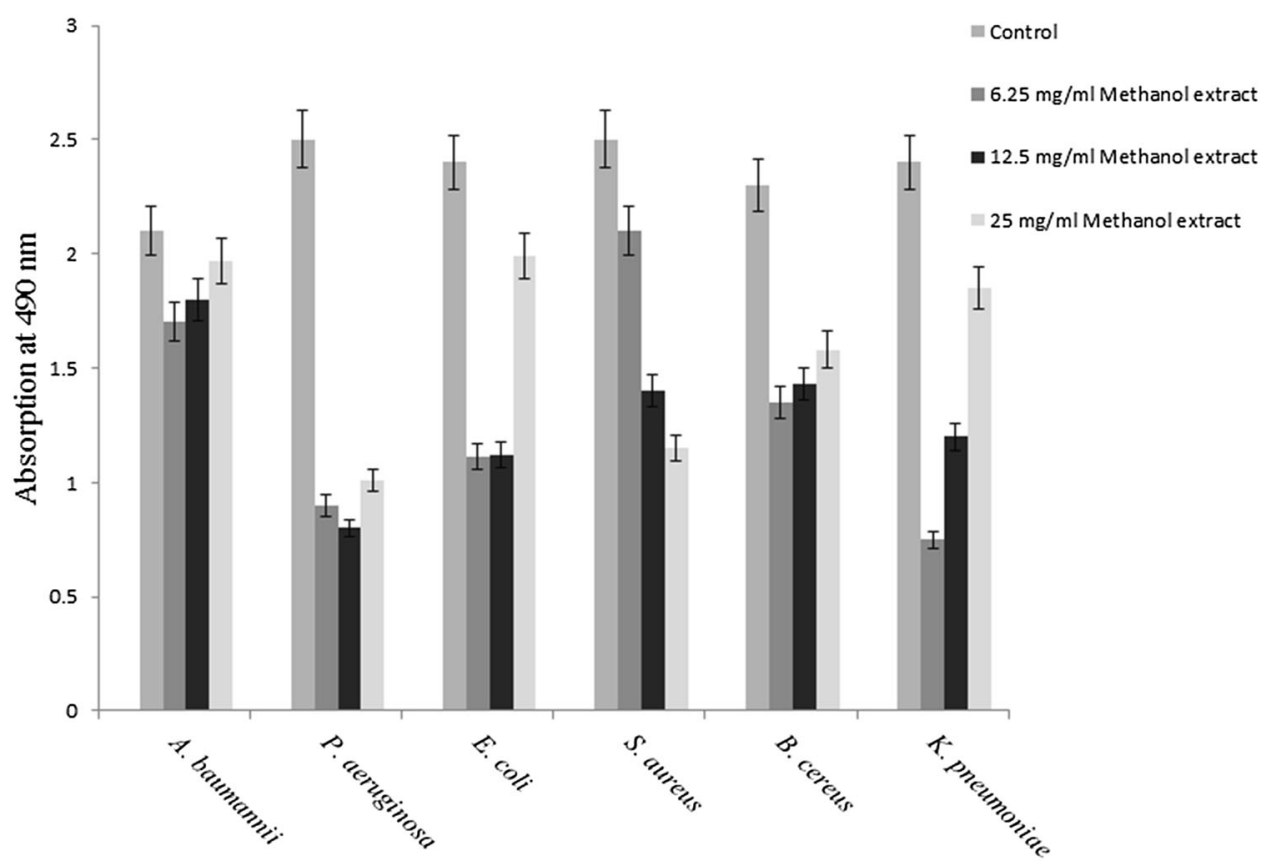

Fig. 4 Efficiency of $S$. haddoni extracts on biofilm metabolic activity (inhibition of dehydrogenase enzyme)

Table 2 Statistical analysis of the results by Duncan's test

\begin{tabular}{|c|c|c|c|c|c|c|c|}
\hline \multirow[t]{2}{*}{ S. haddoni extracts } & \multirow[t]{2}{*}{ Variables } & \multicolumn{3}{|c|}{ Biofilm formation } & \multicolumn{3}{|c|}{ Biofilm destruction } \\
\hline & & $D f$ & Ms & Sig. & $D f$ & Ms & Sig. \\
\hline \multirow[t]{3}{*}{ Tentacle } & Bacteria & 5 & 0.035 & - & 5 & 0.114 & - \\
\hline & Concentration $\left(\mathrm{mg} \mathrm{mL}^{-1}\right)$ & 2 & 0.028 & $*$ & 2 & 0.008 & $* *$ \\
\hline & Total & 7 & & 7 & & & \\
\hline \multirow[t]{3}{*}{ Disc } & Bacteria & 5 & 0.025 & - & 5 & 0.051 & - \\
\hline & Concentration $\left(\mathrm{mg} \mathrm{mL}^{-1}\right)$ & 2 & 0.091 & - & 2 & 0.101 & - \\
\hline & Total & 7 & & 7 & & & \\
\hline \multirow[t]{3}{*}{ Total } & Bacteria & 5 & 0.055 & - & 5 & 0.035 & - \\
\hline & Concentration $\left(\mathrm{mg} \mathrm{mL}^{-1}\right)$ & 2 & 0.010 & $*$ & 2 & 0.090 & $* *$ \\
\hline & Total & 7 & & 7 & & & \\
\hline
\end{tabular}

The variable parameters in this analysis were type of bacteria and the concentrations of each extracts. This statistical analysis was done in three levels of significance

$M s$ mean square, $D f$ degrees of freedom, Sig. significant

$* p<0.05, * * p<0.01, * * * p<0.001,-$ no significant level

Their results confirmed that these compounds from sea anemone had sufficient antibacterial activity and the best inhibition belong to A. hydrophila (Gunasundari et al. 2013).

The novelty of this research is that this research is the first report on the antimicrobial activity of sea anemone at the Persian Gulf; until now, we have not seen any article that studies the antimicrobial activity of this marine animal. Also, the antibiofilm activity of marine animals has not been described until now and this consider as another novelthy of current research.

However, a few researches were also carried out on the antimicrobial activity of toxins produced by the marine sea anemone. Ghosh et al. (2011) studied the antimicrobial activity of the toxin produced by $H$. magnifica and $S$. meritensis and identified that some extracts showed highest inhibition against $S$. aureus (69.23\%) and S. Typhi (63.16\%) (Ghosh et al. 2011). 
Table 3 Chemical composition of Stichodactyla haddoni (Haddon's sea anemone) extracts obtained by GC-MS

\begin{tabular}{lllccc}
\hline No. & Compounds & Formula & $\begin{array}{l}\text { Ret. } \\
\text { time }\end{array}$ & $\begin{array}{c}\text { Area } \\
\%, \text { of } \\
\text { total }\end{array}$ \\
\hline 1 & Propane, 2,2-dimethoxy- & $\mathrm{C}_{5} \mathrm{H}_{12} \mathrm{O}_{2}$ & 2.995 & $2.048 \mathrm{e}+4$ & 0.063 \\
2 & Methyl isobutyl ketone & $\mathrm{C}_{6} \mathrm{H}_{12} \mathrm{O}$ & 3.598 & $3.099 \mathrm{e}+4$ & 0.095 \\
3 & 3-Benzylsulfanyl-3-fluoro-2-trifluoromethyl-acrylonitrile & $\mathrm{C}_{11} \mathrm{H}_{7} \mathrm{~F}_{4} \mathrm{NS}$ & 3.900 & $2.038 \mathrm{e}+4$ & 0.062 \\
4 & 2-Pentanone, 4-hydroxy-4-methyl- & $\mathrm{C}_{6} \mathrm{H}_{12} \mathrm{O}_{2}$ & 4.722 & $9.636 \mathrm{e}+4$ & 0.295 \\
5 & p-Xylene & $\mathrm{C}_{8} \mathrm{H}_{10}$ & 5.477 & $2.071 \mathrm{e}+4$ & 0.063 \\
6 & Cyclohexane, 1,3,5-trimethyl-2-octadecyl & $\mathrm{C}_{27} \mathrm{H}_{54}$ & 16.327 & $1.811 \mathrm{e}+4$ & 0.055 \\
7 & 1-Heptadecyne & $\mathrm{C}_{17} \mathrm{H}_{32}$ & 18.352 & $1.308 \mathrm{e}+5$ & 0.400 \\
8 & 1-Hexadecanol & $\mathrm{C}_{16} \mathrm{H}_{34} \mathrm{O}$ & 18.545 & $2.525 \mathrm{e}+5$ & 0.772 \\
9 & Hexadecanoic acid, methyl ester & $\mathrm{C}_{17} \mathrm{H}_{34} \mathrm{O}_{2}$ & 18.998 & $3.180 \mathrm{e}+5$ & 0.972 \\
10 & 9,12-Octadecadienoic acid (Z,Z) & $\mathrm{C}_{18} \mathrm{H}_{32} \mathrm{O}_{2}$ & 20.334 & $4.633 \mathrm{e}+4$ & 0.142 \\
11 & Methyl stearidonate & $\mathrm{C}_{19} \mathrm{H}_{30} \mathrm{O}_{2}$ & 20.577 & $3.171 \mathrm{e}+5$ & 0.969 \\
12 & Methyl 16-methyl-heptadecanoate & $\mathrm{C}_{19} \mathrm{H}_{38} \mathrm{O}_{2}$ & 20.919 & $1.319 \mathrm{e}+5$ & 0.403 \\
13 & Methyl 5,8,11,14,17-eicosapentaenoate & $\mathrm{C}_{21} \mathrm{H}_{32} \mathrm{O}_{2}$ & 22.253 & $3.277 \mathrm{e}+5$ & 1.002 \\
14 & cis-7,10,13,16-Docosatetraenoic acid, methyl ester & $\mathrm{C}_{23} \mathrm{H}_{38} \mathrm{O}_{2}$ & 23.845 & $1.874 \mathrm{e}+5$ & 0.573 \\
15 & Methyl 7,10,13,16,19-docosapentaenoate & $\mathrm{C}_{23} \mathrm{H}_{36} \mathrm{O}_{2}$ & 23.941 & $2.261 \mathrm{e}+5$ & 0.691 \\
16 & 17-(1,5-Dimethylhexyl)-10,13-dimethyl-2,3,4,7,8,9,10,11,12,13,14,15,16,17- $-\mathrm{C}_{27} \mathrm{H}_{46} \mathrm{O}$ & 31.056 & $2.922 \mathrm{e}+6$ & 8.933 \\
& tetradecahydro-1H-cyclopenta[ & $\mathrm{C}_{28} \mathrm{H}_{48} \mathrm{O}$ & 32.958 & $1.792 \mathrm{e}+6$ & 5.480 \\
17 & Campesterol & & & &
\end{tabular}

John et al. (2015) evaluated the inhibitory effect of S. haddoni and Anthopleura elegantissima extracts (diethyl ether) against Gram-positive and Gram-negative bacteria.

In the current research, we evaluated the antibacterial and antibiofilm activity of one species of sea anemone against six antibiotic-resistant bacteria. This research is the first report on antimicrobial activity of sea anemone (Persian Gulf environment). The Persian Gulf is a diver's marine ecosystem in the world, but a few researches were performed on the extraction of bioactive compounds from this marine ecosystem. Our results on the antibacterial activity of three parts of $S$. haddoni extracts against planktonic forms of six bacteria confirmed that these extracts have sufficient inhibition. However, the rate of inhibition against different bacteria varied. Also, the effect obtained with agar well plate method for antimicrobial assay was stronger than that obtained with diffusion method. This result is expected because the diffusion of sea anemone extracts into agar well is better than paper disc; thus, the zone of inhibition will be bigger than disc.

The values recorded in this study for the antibacterial activity of extracts are according to the values reported by the mentioned researcher (Bragadeeswaran et al. 2011; Bhosale et al. 2002). Although the method for extraction of bioactive compounds in this research was different than another researcher, a few differences in the results were observed in this study compared to the published research. The MIC and MBC recorded in this study were low, and these results confirmed that these extractions can be active in lower concentration.

The antibiofilm activity of bioactive compounds from marine animals was low investigated. Bragadeeswaran et al. (2011) studied the antifouling activity of two sea anemone extracts (which include Heteractis aurora and $H$. magnifica) against seven bacterial biofilms. They concluded that the crude extract of H. magnifica showed a maximum inhibition zone $(18 \mathrm{~mm})$ against Pseudomonas sp. and E. coli. The minimum inhibition zone $(3 \mathrm{~mm})$ was observed against $P$. aeruginosa, Micrococcus $s p$., and $B$. cereus for methanol, acetone, and dichloromethane extracts, respectively (Bragadeeswaran et al. 2011). Also, Bhosale et al. (2002) have reported antimicrobial property of marine organisms against bacteria that were isolated from test panels biofilm (Bhosale et al. 2002).

In this research, the antibiofilm activity of the sea anemone was investigated. Three parts of $S$. haddoni were selected for this analysis that include tentacle, disc, and a mixture of disc and tentacles. The results confirmed that the inhibition of biofilm structures of six pathogenic bacteria by these extracts was higher than the destruction of biofilms of these bacteria. In another hand, when the bacterial biofilms are forming, the extracts have better inhibitory effects than formed biofilms. These results show that the antimicrobial 
compounds from $S$. haddoni were effective on bacterial attachment. However, when the bacteria were established on the surface, these inhibitory effects decrease dramatically.

The data obtained from antibiofilm activity and inhibition of the metabolic activity of bacteria by $S$. haddoni extracts confirmed that Gram-positive bacteria (B. cereus, S. aureus) were more resistant than Gramnegative bacteria (E. coli, A. baumannii, K. pneumoniae, P. aeruginosa). Since, the Gram-positive bacteria have thick cell wall compare to Gram-negative bacteria then the antimicrobial agents have low killing effect on Gram-positive bacteria. This study is the first report on antibiofilm activities of S. haddoni and until now, there are not any publications in this field.

The antimicrobial constitutes of $S$. haddoni were determined by GC-MS. The results confirmed that the major compounds of $S$. haddoni extract were aliphatic compounds. These compounds were described also by another researcher as antimicrobial agents, some examples were explained as follows: Tamokou et al. (2011) analyze the chemical structures of Brillantaisia lamium. They found that this plant has four compounds including: Aurantiamide acetate, Lupeol, Lespedin, Sitosterol 3-O- $\beta$-D-glucopyranoside and a mixture of sterols: Campesterol, Stigmasterol, and $\beta$-sitosterol. These compounds exhibited both antibacterial and antifungal activities that varied with a microorganism $(\mathrm{MIC}=6.25-1000 \mu \mathrm{g} / \mathrm{ml}$ ) (Tamokou et al. 2011).

In this study, we detect Campesterol in sea anemone; this material was reported by Takoma et al as antibacterial agents.

Kumar et al. (2011) studied the antibacterial activity of alga Spirulina, also they determined the chemical composition of this alga. Their results revealed that the major antibacterial compounds in this alga were 1-Octadecene and 1-Heptadecane. In our study, we identified these materials as antimicrobial agents in sea anemone (Kumar et al. 2011).

\section{Conclusion}

Data obtained (according to studies of other research groups) revealed that the marine organisms and especially sea anemone are an important source of bioactive compounds that can be used to prevent bacterial biofilm. The results of this preliminary study confirmed that $S$. haddoni's extract had sufficient inhibitory effect against principal pathogenic bacteria (e.g., Pseudomonas). The possible application of these bioactive materials originates from this particular sea anemone can be proposed for future studies (of microbial ecology and biomedical application).

Open Access This article is distributed under the terms of the Creative Commons Attribution 4.0 International License (http:// creativecommons.org/licenses/by/4.0/), which permits unrestricted use, distribution, and reproduction in any medium, provided you give appropriate credit to the original author(s) and the source, provide a link to the Creative Commons license, and indicate if changes were made.

\section{References}

Afreenish H, Javaid U, Kaleem F, Omair M, Khalid A, Iqbal M (2011) Evaluation of different detection methods of biofilm formation in the clinical isolates. Braz J Infect Dis 15(4):305-311. https://doi.org/10.1016/S1413-8670(11)70197-0

Atray D, Atray M (2015) Correlation between biofilm production and antibiotic resistance pattern in uropathogenic Escherichia coli in tertiary care hospital in Southern Rajasthan, India. Int J Curr Microbiol App Sci 4(7):640-646

Bhosale SH, Nagle VL, Jagtap TG (2002) Antifouling potential of some marine organisms from India against species of Bacillus and Pseudomonas. Mar Biotechnol 4:111-118. https://doi.org/10.1007/s10126-001-0087-1

Boyanova L, Gergova G, Nikolov R, Derejian S, Lazarova E, Katsarov N (2005) Activity of Bulgarian propolis against 94 Helicobacter pylori strains in vitro by agar-well diffusion, agar dilution and disc diffusion methods. J Med Microbiol 54(5):481-483. https://doi.org/10.1099/jmm.0.45880-0

Bragadeeswaran S, Thangaraj S, Prabhu K, Rani SRS (2011) Antifouling activity by sea anemone extracts against marine biofilm bacteria. Lat Am J Aquat Res 39(2):385-389. https://doi.org/10.3856/vol39-issue2-fulltext-19

Eash-Loucks WE, Fautin DG (2012) Taxonomy and distribution of sea anemones (Cnidaria:Actiniaria and Corallimorpharia) from deep water of the northeastern Pacific. ZooTaxa 3375:1-80

Frazão B, Vasconcelos V, Antunes A (2012) Sea Anemone (Cnidaria, Anthozoa, Actiniaria)Toxins. Marine Drugs 10(8):1812-1851

Ghosh S, Ajithh Kumar TT, Balasubramanian T (2011) Characterization and antimicrobial properties from the sea anemones [Heteractics magnifica and Stichodactyla mertensii] toxins. Arch Appl Sci Res 3(4):109-117 
Gunasundari V, Ajith Kumar TT, Kumaresan S, Balagurunathan R, Balasubramanian T (2013) Isolation of aliphatic-antibiotic compounds from marine invertebrate, Heteractis magnifica "Quoy \& Gaimard 1833" against captive marine ornamental fish pathogens. Indian J Geomar Sci 42:807-811

Hamayeli H, Shoshtari A, Hassanshahian M, Askari M (2016) Study the antimicrobial activity of six marine sponges and three parts of sea anemone on Candida Albicans. J Coast Life Med 4(8):122-129. https://doi.org/10.12980/jclm.4.2016j6-76

Hutton DMC, Smith VJ (1996) Antibacterial properties of isolated amoebocytes from the sea anemone Actinia equine. Biol Bull 191(3):441-451

Jabra-Rizk MA, Meiller TF, James CE, Shirtliff ME (2006) Effect of farnesol on Staphylococcus aureus biofilm formation and antimicrobial susceptibility. Antimicrob Agents Chemother 50(4):1463-1469. https://doi.org/10.1128/AAC.50.4.1463-1469. 2006

John ST, Velmurugan S, Nagaraj DS, Kumaran S, Pugazhvendan SR (2015) Antimicrobial activity of sea anemone Stichyodactyla hadonii and Anthopleura elegantissima extracts against human pathogens. Int J Adv Res Biol Sci 2(6):27-35

Khoddami M, Sheikh Hosseini M, Hassanshahian M (2018) Antibacterial activity of Semenovia suffruticosa (essential oil) against pathogenic bacteria and determination of chemical composition of essential oils by gas chromatography-mass spectrometry analysis in four regions of Kerman. J Diet Suppl 29:1-11. https://doi.org/10.1080/19390211.2018.147216

Kumar V, Bhatnagar AK, Srivastava JN (2011) Antibacterial activity of crude extracts of Spirulina platensis and its structural elucidation of bioactive compound. J Med Plant Res 5(32):7043-7048. https://doi.org/10.5897/jmpr11.1175

Lazarova V, Pierzo V, Fontvielle D, Manem J (1994) Integrated approach for biofilm characterization and biomass activity control. Water Sci Technol 29:345-354. https://doi.org/10.2166/wst.1994.0361

Mashhadi M, Fakhri J, Saeedi S, Hassanshahian M, Abkhoo A (2016) Antimicrobial effects of medicinal plants collected in zabol, iran, on pathogenic food pathogenic. J Med Bacteriol 5(3):18-28

Masoumipour F, Hassanshahian M, Jafarinasab T (2018) Antimicrobial activity of combined extracts of trachyspermum, thymus and pistachio against some pathogenic bacteria. J Kern Med Univ 25(2):153-163

Mohammadi M, Masoumipour F, Hassanshahian M, Jafarinasab T (2019) Study the antibacterial and antibiofilm activity of Carum copticum against antibiotic-resistant bacteria in planktonic and biofilm forms. Microb Pathog 129:99-105. https://doi. org/10.1016/j.micpath.2019.02.002

Mohsenipour Z, Hassanshahian M (2015) The inhibitory effect of Thymus vulgaris extracts on the planktonic form and biofilm structures of six human pathogenic bacteria. Avicen J Phytomed 5(4):309-317

Mohsenipour Z, Hassanshahian M (2016) Antibacterial activity of Euphorbia hebecarpa alcoholic extracts against six human pathogenic bacteria in planktonic and biofilm forms. Jundishapur J Microbiol. https://doi.org/10.5812/jjm.34701e34701

Odonkor ST, Addo KK (2011) Bacteria resistance to antibiotics: recent trends and challenges. Int J Biol Med Res 2(4):1204-1210

O'Toole GA, Kolter R (1998) Initiation of biofilm formation in Pseudomonas fluorescens WCS365 proceeds via multiple, convergent signalling pathways: a genetic analysis. Mol Microbiol 28(3):449-461. https://doi.org/10.1046/j.1365-2958.1998. 00797.x

Prakash WG, Babu S, Ravikumar S, Kathiresan K, Arul Prathap S, Chinnapparaj S, Marian MP, Liakath Alikhan S (2007) Antimicrobial activity of tissue and associated bacteria from benthic sea anemone Stichodactyla haddoni against microbial pathogens. J Environ Biol 28(4):789-793

Prasanna SS, Doble M (2008) Medical biofilms: its formation and prevention using organic molecules. J Indian Inst Sci 88(1):27-35

Raghunathan C, Raghuraman R, Choudhury S, Venkataraman K (2014) Diversity and distribution of sea anemones in India with special reference to Andaman and Nicobar Islands. Rec Zool Surv India 114(2):269-294

Rani Juneius CE, Selvin J (2012) Axinella donani: a marine sponge, as potential source of therapeutic compounds. J Microbiol Biotechnol Res 2(1):223-234

Rocha J, Francisco JRCC, Peixe L, Gomes NCM, Calado R (2014) Optimization of preservation and processing of sea anemones for microbial community analysis using molecular tools. Sci Rep 4:6986. https://doi.org/10.1038/srep06986

Rosenberg M, Rosenberg E (1981) Role of adherence in growth of Acinetobacter calcoaceticus RAG-1 to hexadecane. J Bacteriol 148:51-57

Sadeghian I, Hassanshahian M, Sadeghian S, Jamali S (2012) Antimicrobial effects of Quercus brantii fruits on bacterial pathogens. Jundishapur J Microbiol 5(3):465-469. https://doi.org/10.5812/jjm.3376

Saeidi S, Amini Boroujeni N, Ahmadi H, Hassanshahian M (2015) Antibacterial activity of some plant extracts against extendedspectrum beta-lactamase producing Escherichia coli isolates. Jundishapur J Microbiol. https://doi.org/10.5812/jjm. $15434 \mathrm{e} 15434$

Sandasi M, Leonard CM, Viljoen AM (2008) the effect of five common essential oil components on Listeria monocytogenes biofilms. Food Control 19:1070-1075. https://doi.org/10.1016/j.foodcont.2007.11.006

Schlesinger A, Kramarsky-Winter E, Rosenfeld H, Armoza-Zvoloni R, Loy Y (2010) Sexual plasticity and self-fertilization in the sea anemone Aiptasia diaphana. PLoS ONE 5(7):e11874. https://doi.org/10.1371/journal.pone.0011874

Sepehri Z, Javadian F, Khammari D, Hassanshahian M (2016) Antifungal effects of the aqueous and ethanolic leaf extracts of Echinophora platyloba and Rosmarinus officinalis. Curr Med Mycol 2(1):16-25. https://doi.org/10.18869/acadpub.cmm.2.1. 30

Silveira CP, Torres-Rodríguez JM, Alvarado-Ramírez E, Murciano- Gonzalo F, Dolande M, Panizo M (2009) MICs and minimum fungicidal concentrations of amphotericin B, itraconazole, posaconazole and terbinafine in Sporothrix schenckii. J Med Microbiol 58(12):1607-1610. https://doi.org/10.1099/jmm.0.007609-0

Simões M, Simões L, Vieira MJ (2010) A review of current and emergent biofilm control strategies. LWT Food Sci Technol 43:573-583. https://doi.org/10.1016/j.1wt.2009.12.008 
Soares GMS, Figueiredo LC, Faveri M, Cortelli SC, Duarte PM, Feres M (2012) Mechanisms of action of systemic antibiotics used in periodontal treatment and mechanisms of bacterial resistance to these drugs. J Appl Oral Sci 20(3):295-309. https:// doi.org/10.1590/S1678-77572012000300002

Stewart PS, Costerton JW (2001) Antibiotic resistance of bacteria in biofilms. Lancet 358(9276):135-138. https://doi.org/10.1016/ S0140-6736(01)05321-1

Subramanian B, Sangappellai T, Chandra Rajak R, Diraviam B (2011) Pharmacological and biomedical properties of sea anemones Paracondactylis indicus, Paracondactylis sinensis, Heteractis magnifica and Stichodactyla haddoni from East coast of India. Asian Pac J Trop Dis 4:722-726. https://doi.org/10.1016/S1995-7645(11)60181-8

Tamokou JDD, Kuiate JR, Tene M, Nwemeguela TJK, Tane P (2011) The antimicrobial activities of extract and compounds isolated from Brillantaisia lamium. Iran J Med Sci 36(1):24-31

Thangaraj S, Bragadeeswaran S (2012) Assessment of biomedical and pharmacological activities of sea anemones Stichodactyla mertensii and Stichodactyla gigantea from Gulf of Mannar Biosphere Reserve, southeast coast of India. J Venom Anim Toxins Incl Trop Dis 18(10):53-61. https://doi.org/10.1590/S1678-91992012000100007

Thangaraj S, Bragadeeswaran S, Suganthi K, Sri Kumaran N (2011) Antimicrobial properties sea anemone Stichodactyla mertensii and Stichodactyla gigantea from Mandapam coast of India. Asian Pac J Trop Biomed 1(1):43-46. https://doi.org/ 10.1016/S2221-1691(11)60120-2

Williams JM, Barnhofer T, Crane C, Herman D, Raes F, Watkins E, Dalgleish T (2007) Autobiographical memory specificity and emotional disorder. Psychol Bull 133(1):122-48

\section{Publisher's Note}

Springer Nature remains neutral with regard to jurisdictional claims in published maps and institutional affiliations. 